\title{
Paisagens sonoras, trilhas musicais: retratos sonoros do Brasil
}

\author{
Heloísa de A. Duarte Valente (UMC; PPGMUS-ECA-USP, São Paulo) \\ musimid@gmail.com; heloisa.valente@pq.cnpq.br
}

Resumo: 0 presente texto parte dos pressupostos de que: 1) a música é componente de relevo da paisagem sonora (SCHAFER, 2001); da mesma maneira, a paisagem sonora interfere nos processos perceptivos e na formação do gosto estético; 2) a música veiculada pela mídia é construto da vida cotidiana, pois a própria música engendra modelos e formas de comportamento. Tendo como referência essas premissas, este texto analisa peças de repertório musical que, de certa maneira, representam o Brasil, ao longo de seus governos e governantes. Tomo, para este ensaio, a paisagem sonora do período relativo ao final do século $X X$, em que governaram os presidentes Fernando Henrique Cardoso e Luiz Inácio Lula da Silva. Acredito que traços particulares presentes na canção midiática formam uma rede de signos (às vezes discretos) que acabam por imprimir, indelevelmente, à cultura de origem, uma feição muito particular. Ocorre que, até o momento presente, estes signos não demonstram terem sido objeto de análises mais detalhadas. Um estudo desses elementos poderá contribuir para compreender melhor a dinâmica social das culturas, pela figura de seus governantes e governos, para além do que nos vem sendo oferecido, de forma estereotipada e simplista.

Palavras-chave: paisagem sonora no Brasil; música popular e memória musical; canção e semiótica musical.

\section{Soundscapes, soundtracks: Brazilian sound portraits}

Abstract: This paper departs from the following assumptions 1) music is a prominent part of the soundscape (SCHAFER, 2001) and likewise, the soundscape interferes with compositional processes and the development of the aesthetical taste, 2) pieces of music broadcasted in the media are constituents of everyday life, since music itself produces habits and models of behavior. Referring to these suppositions, this text intends to analyze some pieces of musical repertoire which in a certain extent represents Brazil as a country, through their governments and presidents. For this purpose, I will analyze the soundscape of the period concerning the late twentieth century, when Fernando Henrique Cardoso and Luiz Inácio Lula da Silva were presidents. I believe that particular features in media songs might engender a network of signs (sometimes discreet ones) which could stamp its marks in culture in a very special way. It should be stressed that such approach seems not to have been subject of careful study. An analysis of these discrete elements could contribute to understand how social dynamics of cultures occurs, beyond the stereotyped and naive approaches.

Keywords: soundscape in Brazil; popular songs and musical memory; song and musical semiotics.

\section{Um Brasil que se conhece pelos ouvidos}

Antes de iniciar esta exposição, cabe mencionar a origem de tal preocupação investigativa. Este texto é parte de um ensaio longo cujo tema envolve as paisagens sonoras no Brasil, tendo como base as "trilhas sonoras" implantadas pelos governos e respectivos governantes. A motivação que me levou a escrevê-lo deu-se de modo quase acidental há vários anos, quando assisti a uma entrevista ao crítico musical Nelson Motta, pela televisão. Ao comentar sobre o panorama das músicas no Brasil, Motta aventou uma hipótese muito instigante: governos e governantes têm uma trilha musical que os identifica e caracteriza; mais que isso, os gêneros musicais imprimem uma marca indelével, inconfundivel. Sugeria que modas e modismos musicais surgiam ao sabor do ambiente sociopolítico. Seguindo tal raciocínio, Fernando Collor, presidente de então, coadunava-se com os sertanejos; do mesmo modo que José Sarney corresponderia à lambada e, Juscelino Kubitschek, à Bossa Nova. Seguiram-se outros exemplos. Memorizei as considerações do crítico e passei a refletir sobre o assunto. (infelizmente, as referências à entrevista se perderam...) A curiosidade me atiçou, levando-me a estabelecer uma série de paralelos e a tomar notas esparsas. Devo, pois, a Nelson Motta, "mote" inicial para este exercício de "clariaudiência"1 que aqui segue. Acredito que o tema mereça especial

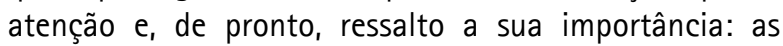
mídias pontuam praticamente todas as atividades da vida cotidiana, em quantidade e extensão cada vez mais 
abrangente. Dentre todas elas, a música - sobretudo sob a modalidade "canção"- parece onipresente nas linguagens audiovisuais, quer como trilha sonora, quer como música de fundo (jingles publicitários, tema de abertura de peças de teledramaturgia,noticiários, leitmotiven de personagens nas telenovelas etc.); na vida comezinha,a música "infiltra-se" no território da vida íntima e pessoal (ou, mesmo o "invade") através dos toques de telefone, games, além da já conhecida e polêmica música-ambiente (Muzak). Essa existência se verifica tanto no ambiente doméstico, quanto nos espaços públicos e institucionais. Posto isso, não parece exagerado afirmar que os signos musicais representam e testemunham o seu tempo e o tempo ao qual fazem referência.

Raciocinando dessa maneira, a analogia proposta por Nelson Motta está longe de constituir uma prática retórica, de exibicionismo do seu conhecimento sobre repertórios musicais; ao contrário, trata-se, antes de tudo, de um convite (e uma provocação) ao leitor curioso para deixar-se enveredar por um campo ainda pouco explorado nos estudos acadêmicos - o mundo que se faz conhecer pelos ouvidos (VALENTE, 2002). 0 conjunto de obras (e as variações da paisagem sonora, em suas várias circunstâncias) não apenas constroem a imagem do governante, desde a sua candidatura, até a tomada de poder, mas também, em certa medida, identificam programas de governo, ao longo do seu mandato. A composição da imagem (sonora), por intermédio de peças musicais, estabelece formas ativas de comunicação entre sistemas, orientação ideológica de governo, governantes e governados. Tal como a "trilha sonora" de uma extensa peça de dramaturgia, a trilha sonora dos governos põe em cena as tramas da vida em sociedade, em momentos de júbilo e conflito; aceitação e recusa; concordância e repúdio; guerra e paz, amor e ódio... Ocorre que esta comunicação se faz, em larga medida, de maneira intuitiva: os códigos existem, sendo geralmente decifrados de maneira espontânea. Em outras palavras, parece existir uma forma correspondente nas diversas configurações das paisagens sonoras à máxima popular "o hábito faz o monge". 0 que não se verifica é a formulação sistemática a ser aplicada convencionalmente. Este ensaio tem a pretensão de dar início a essa empreitada. Para tanto, levará em conta, alguns pressupostos: 1) a música é componente de incontestável importância na paisagem sonora ${ }^{2}$ (SCHAFER, 2001); esta, por sua vez, interfere nos processos comunicacionais, na recepção (uma vez que modifica a sensibilidade da escuta); 2) a paisagem sonora é capaz de engendrar modelos e formas de ouvir, pensar e compor música; 3) em decorrência do item 2), infere-se que a música veiculada pelas mídias é construto não apenas do mercado fonográfico e seus mandatários, mas também resulta de uma incorporação de hábitos de escuta desenvolvidos e cristalizados na vida cotidiana, pela própria repetição contínua na escuta de determinado repertório (voluntariamente, ou não). Tendo apresentado estas premissas iniciais, passo a alguns conceitos de base.

\section{Retratos sonoros: à procura de uma conceituação própria}

Antes de proceder a uma análise das obras que identificam, rotulam, salientam,maculam, exaltam - ou até mesmo depõem-governantes e respectivos governos, cabe fazer duas observações iniciais. A primeira delas refere-se ao conceito de "paisagem sonora" (adaptação do neologismo soundscape), criado pelo compositor e R. Murray SCHAFER (2001). Para o compositor canadense, os estudos da paisagem sonora envolvem um campo interdisciplinar de pesquisas referentes ao ambiente acústico, não importando sua natureza. São paisagens sonoras as situações e circunstâncias em que os eventos sonoros se desenrolam no tempo e no espaço, incluindo-se próprias transfigurações de um mesmo ambiente: a paisagem sonora de um mesmo espaço físico se transfigura ao longo das horas do dia, das estações do ano; o transcorrer dos séculos também imprime variações. A rigor, a paisagem sonora tende a ser mais barulhenta nas grandes cidades, devido a uma maior ocorrência de eventos sonoros simultâneos, sejam eles motivados por pessoas ou outras fontes. Acrescente-se que a evolução tecnológica vem trazendo um aumento progressivo na quantidade de objetos produtores de ruídos, congestionando a paisagem sonora. Os sons naturais -sobretudo animais- tornaramse raros ou menos frequentes.

Outro marco conceitual a destacar é a música que aqui será analisada. Posto que a grande maioria das obras musicais que fazem referência mais ou menos direta a governantes, governos e população se dão por variantes da forma canção, é necessário, antes de prosseguir, estabelecer uma distinção entre as denominações "canção popular" e "canção das mídias". Parto do pressuposto de que o conceito de canção popular é impreciso, podendo-se estender a uma gama diversa de obras (NEDER, 2010) ${ }^{3}$. Muito embora pareça um conceito autorreferente, talvez até pelo seu uso trivial pelo senso comum, não há um consenso, uma definição clara sobre o que se denomina canção popular (GONZÁLEZ, 2001). De maneira precária, conceitua-se como uma peça musical, composta sobre texto verbal, difundida pelos diversos meios de comunicação. Tal definição, levada ao extremo pode encampar desde a canção tradicional, de origem antiga, até a ária de ópera, adequada à transmissão por alto-falantes. Dada essa fragilidade conceitual, opto pela denominação canção das mídias (VALENTE, 2003): a canção concebida para ser veiculada pelas mídias (inicialmente, sonoras, sucedida pelas audiovisuais), acolhendo as normas e possibilidades tecnológicas disponíveis; ou, ainda, a canção que, mesmo oriunda de outro contexto (árias de ópera romântica, cantigas folclóricas, tradicionais e outras compostas para se executar ao vivo e sem aparatos) tenha-se adaptado aos padrões da canção concebida para o disco, tendo seus parâmetros (duração, variação de intensidade e andamento, instrumentação etc.) controláveis segundo outros referenciais alheios ao projeto do compositor e, não raro, o próprio intérprete. 
Ainda que a maioria das canções midiáticas não resulte da leitura de uma partitura pré-existente (convencional, em pentagrama ou mesmo por cifras), não se excluem dessa categoria aquelas que tiverem, em sua base, 0 suporte escrito. A canção midiática deve ser composta, executada, difundida e desfrutada tendo em conta os recursos oferecidos pelo conjunto de técnicas e estéticas do som (e/ou do audiovisual) vigente. Este compósito técnica-estética estará, por sua vez, submetido a outros condicionantes, como a esfera político-econômica (das gravadoras e, por extensão, de todas as empresas da comunicação), orientações ideológicas diversas, de maneira mais ou menos significativa (instituições de poder como estado, religião). Na maioria das vezes, a canção midiática é, em sua essência, pensada como mercadoria ou, pelo menos, tende a converter-se numa ${ }^{4}$. Essa orientação não impede que a composição resulte numa obra de razoável complexidade formal. Ocorre, ainda que algumas canções se consagrem no gosto popular, a ponto de se transformarem em "monumentos sonoros históricos", quer um sob o aspecto musical ou de outra natureza. Aqui se agrupam as obras que ganharam destaque em razão de suas qualidades formais (vide os clássicos Aquarela do Brasil, Carinhoso, Desafinado... quanto aquelas que se tornaram memória em virtude justamente da imagem negativa que fincaram (Florentina de Jesus, Uma vida só). A canção das mídias terá na performance ${ }^{5}$ (ZUMTHOR, 1997) o seu modelo principal, que englobará um amplo leque de elementos característicos e diferenciais.

Uma terceira observação toca ao termo performance. Para além das acepções mais conhecidas ("execução", "interpretação", "desempenho" etc.) o vocábulo deve aqui ser compreendido como um conceito estabelecido pelo erudito Paul ZUMTHOR (1997), que o define como uma ação complexa, que envolve múltiplos fatores: emissor, receptor, circunstâncias que envolvem o processo comunicativo. No caso da música, a performance não se restringe à ação do (execução) do instrumentista, à interpretação (do ator, poeta, cantor). Por fim, cabe frisar que o vocábulo "mídia" não se limita ao sentido conferido pelo senso comum (grande imprensa, publicidade etc.), mas o próprio aparato capaz de, ele próprio, engendrar processos comunicativos (SANTAELLA, 1996).

\section{Referências teórico-metodológicas}

Antes de descrever os procedimentos teóricometodológicos que orientaram esta pesquisa, algumas observações iniciais precisam ser feitas. De início, é fato que tratar da produção musical da última década do segundo milênio é incumbência espinhosa, por várias razões: dentre elas, a própria proximidade temporal impede o distanciamento adequado do observador, impossibilitando-o de efetuar uma análise precisa dos signos que de fato hajam-se fixado como memória musical, ou cultural. De outra parte, há uma notável escassez de fontes de cunho crítico, sobre a produção musical do período relativo aos últimos vinte anos, quando a abordagem se faz a partir da linguagem musical ${ }^{6}$. Enumerar gêneros e tendências musicais pela sua importância é, igualmente, problemático face à multiplicidade de critérios possíveis?

Sobretudo, o que se aponta aqui como mais frágil consiste na comparação quase direta de elementos aparentemente incomparáveis e distantes entre si: repertórios musicais, presidentes e as respectivas paisagens sonoras de governo. As vinculações parecem muito abruptas e a empreitada corre o risco de não passar de uma sequência de metáforas... Ocorre que as metáforas são abstrações de elementos sensíveis capturados da realidade. (Todavia, não costumam ser adotadas para embasar teses acadêmicas....). Esse terreno pantanoso não me intimidou de levar adiante esse exercício de clariaudiência: a abordagem semiótica permite estabelecer interfaces entre linguagens diversas, de maneira pertinente. Para tanto, existem as teorias que orientam a análise. Se elas não dão conta do objeto em estudo, conforme o esperado, criam-se outros instrumentos subsidiários, que venham a atender às necessidades da pesquisa. Meu histórico como semioticista me levou a dar muita importância ao detalhe, ao "pequeno", ao "desimportante", nos diversos temas que estudo. Acredito que discernir o código musical, em seus elementos mais sutis, é habilidade essencial para decifrar informações sonoras não perceptíveis em uma primeira escuta. 0 estudo, a partir de elementos discretos (pequenas variações de andamento, de pronúncia ou sotaque, modos de ataque etc.), verificáveis na obra musical, poderá contribuir, ainda que modestamente, para compreender melhor a dinâmica social das culturas, para além do que é fornecido, de forma estereotipada e simplória por alguns manuais e obras de divulgação. No caso deste ensaio, proponho uma tentativa de estudar a vida sociopolítica através dos governantes e orientações ideológicas, através da sua música.

Tendo dito isso, proponho-me esboçar uma rápida analogia entre governantes e as respectivas "trilhas sonoras", no Brasil, na passagem dos séculos XX para o XXI. Mais precisamente, tomarei como referência 0 período dos governos Fernando Henrique Cardoso e Luiz Inácio Lula da Silva. Os critérios que embasam esta seleção encontram-se nas seguintes particularidades:

1)Trata-se de um periodo que oferece material empírico que pode ser captado através das histórias de vida e experiências pessoais, de faixas etárias diversas);

2) em termos sociopolíticos, trata-se de um periodo em que os presidentes eleitos, granjeiam uma expressiva representatividade, graças ao expressivo montante de votos diretos obtidos - o que, de algum modo, leva a crer que as manifestações populares possam ser entendidas como espontâneas ${ }^{8}$; 
3) tanto Fernando Henrique Cardoso, como Luís Inácio Lula da Silva têm poder carismático, sendo admirados por uma ampla parcela da população do país. Sendo dessa maneira, os atributos que inevitavelmente se agregam à sua imagem acarretam, inevitavelmente, em repercussões junto à opinião pública. Nesse ponto, é importante recordar que, as diferenças ideológicas e de programa de governo não isola um do outro: num passado de luta pela democracia, ambos compartilhavam ideias e ações conjuntas;

4) o período de governo de ambos os presidentes, em dois mandatos, coincide com o vertiginoso desenvolvimento das mídias digitais que, muito rapidamente desdobraram-se em outras tecnologias,

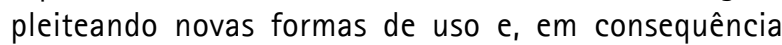
disso, criando de novos hábitos perceptivos;

5) os tempos do pós-modernismo acentuaram as fissuras dos pilares que antes sustentavam categorias definidas, tais como "local", "global", "identidade", "nacional" (etc.); em contrapartida, passaram a mesclarse elementos pertencentes a repertórios diferentes, oriundos de tempos e espaços, a princípio dispares: 0 passado é revisitado, agregando-Ihe qualificativos como vintage, retrô, dentre outros qualificativos (na verdade, uma fetichização da história).

Posto este quadro de referência, esclareço que, além das fontes bibliográficas, apoio-me em outros documentos, tais como anotações diversas sobre eventos, noticias na imprensa, folhetos de divulgação publicitária, filmes e jingles das campanhas políticas etc.. Para a análise dos materiais, adoto a metodologia proposta por Christian MARCADET, estudioso das canções (2007). Importantes são, ainda, os depoimentos e memórias sobre fatos presenciados por testemunhas auditivas, de várias faixas etárias. Neste ponto, a prática de exercícios de "clariaudiência" (SCHAFER, 2001) estimula o depoente a recuperar importantes memórias de acontecimentos ocorridos em caráter individual ou coletivamente, em que a música figure como elemento-chave. A maioria desse repertório musical é composta por canções das midias (VALENTE, 2003).

Por fim, enfatizo: Ainda que as considerações finais permaneçam carregadas de elementos de subjetividade, não deixam de ser resultado de reflexões próprias, fruto de debates de que tenho participado, ao longo dos últimos $\operatorname{anos}^{9}$; outras ideias foram compartilhadas, debatidas, com meus alunos de pós-graduação, no curso que ministro, desde 2006, Música e Cultura das Mídias ${ }^{10}$. Em assim sendo, aquilo que ora que apresento é, inevitavelmente, uma reelaboração dessas formulações. $E$ um ensaio - no sentido literal: impossibilitada de decantar todos os dados subjetivos, adoto uma metodologia pouco convencional, no âmbito dos usuais protocolos acadêmicos - o que não significa num descuido na verificação da autenticidade e confiabilidade das fontes consultadas.

\section{Canção, mídia e memória: A "trilha sonora" do final dos 1900, de FHC a Lula}

0 gigantesco espaço territorial brasileiro - também sonoro - é coberto por um amplo repertório de canções que, em grande monta, habitam a paisagem sonora como memória social, seja ela implantada pela própria comunidade, seja através de iniciativas pessoais. Mas também as gravadoras, através de seus mecanismos de repetição à exaustão acabam por fixar um gosto estético. A despeito de sua existência efêmera, o hit parade engendrado pode vir a desempenhar papel importante, à medida que, de algum modo, a canção de sucesso estabelece paradigmas que permitem identificar (sonoramente) o tempo-espaço de referência de seus consumidores: Isso se explica à medida que os traços particulares presentes na canção midiática formam uma rede de signos (às vezes discretos) que, ao fim e ao cabo, imprimem indelevelmente, à cultura de origem, uma feição muito particular do espírito do seu tempo ${ }^{11}$.

0 hábito de estabelecer paralelos entre modas, modismos e acontecimentos memoráveis é bastante comum, especialmente quando as relações se dão por intermédio de um vínculo afetivo, em alguma instância. Assim, são facilmente recordadas as canções que marcam experiências individuais marcantes, bem como aquelas que se relacionam a acontecimentos coletivos: são os hinos compostos para os diversos certames esportivos (olimpiadas, copas do mundo de futebol), vitórias eleitorais e políticas, rituais e festejos religiosos, cerimônias diversas (coroações, funerais etc.) A associação entre governos de estado e gêneros musicais ocorre de maneira pontual. Neste território a correspondência mostra-se ainda pouco frequente, muito embora o senso comum a faça, de maneira empírica e lúdica. Nas considerações que seguem, procurarei esboçar as linhas iniciais para um estudo de tais relações, através da análise de elementos da paisagem sonora e musical. Limitar-me-ei a apresentar uma lista inicial de obras, autores e intérpretes que marcaram presença na paisagem sonora, fixando as "trilhas sonoras" (quase sempre, representadas por canções) que se tornaram ícones dos governos Fernando Henrique Cardoso (19942002) e Luís Inácio Lula da Silva (2003-2010).

Examinando a paisagem sonora -e, particularmente, musical- do Brasil do período que sucedeu as "diretasjá", verificamos a continuidade de algumas modas e tendências musicais já iniciadas durante o governo José Sarney e que mantiveram sua presença no período Fernando Collor e Itamar Franco: é o caso da lambada, da axé music, da música sertaneja. 0 repertório musical da última década dos 1900 seria alimentado de outras músicas, tais como o pagode, o forró universitário, o rap, o funk carioca, além do denominado "sertanejo romântico". 0 solo sobre o qual este repertório se assentaria: o governo Fernando Henrique Cardoso, logo alcunhado imediatamente $\mathrm{FHC}$, pela mídia impressa.

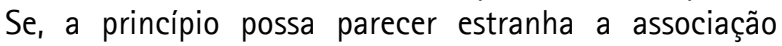
entre uma produção inicialmente voltada às camadas menos favorecidas economicamente e um intelectual 
oriundo da elite intelectual burguesa - é importante ressaltar, logo de início, o panorama que pautou o seu governo. Antes mesmo da tomada de posse, o prestigiado presidente já gozava de prestígio internacional, devido a sua carreira acadêmica bem-sucedida. Por essa época, já se estabeleciam, pouco a pouco, redes de televisão por assinatura, como a MTV, destinada à música jovem (pop, entenda-se). Também se ampliava a comunicação cibernética, o que propiciou a oferta crescente de serviços e produtos culturais à la carte ${ }^{12}$, no geral, peças de entretenimento: longas-metragens "enlatados", séries, variedades e noticiários. Nesse cenário o Brasil passa a consumir o pop internacional pela televisão (grunge, britpop... Nirvana e seu líder Kurt Cobain, Pixies, Red Hot Chili Peppers, REM, Metallica, Guns ' $n$ Roses) ao mesmo tempo em que exporta o heavy metal supranacional que canta em inglês - do grupo Sepultura.

No terreno da produção local, algumas tendências foram surgindo e ganharam força, pelo menos até o final do século $X X$. Dentre eles, destacam-se o pagode (especialmente, o "pagode romântico"), o forró universitário, o rap, o funk - para citar alguns. Trata-se, nos dois primeiros casos, de mutações de gêneros originários de décadas passadas, que foram devidamente desbastados de elementos característicos formais e acrescidos de outros, típicos da estética midiática em vigor. Tais procedimentos visavam atender ao protocolo mercadológico, acrescidos do inevitável e imprescindivel idioleto pop-eletrônico. Isto quer dizer que, via de regra, modalidades regionais, de grande popularidade, como o forró, deixaram de ser ouvidos na sua versão original (sanfona, zabumba e triângulo) e no seu espaço singular: ao ar livre, sem o apoio de tecnologias de amplificação ou de reprodução. Para ser aceito como "moderno" - consumível, entenda-se...- teve de se adaptar aos moldes da música pop e sua estética: "eletrificado", com a adoção do "teclado", bateria (eletrônica) tornouse a receita básica para o sucesso da versão "forró universitário". Muito distante do Trio Nordestino, ou o antológico Luiz Gonzaga, esta versão equivocadamente afiliada à música de raiz (autêntica), para ser tocada em espaços abertos, não escapa do padrão estético ditado pelas majors: são sequências de um mesmo repertório feito para animar festinhas de pessoas cujos ouvidos ficam satisfeitos com altos decibéis de excitação, para se "curtir" num salão fechado e climatizado. A semelhança entre as canções e os vários grupos que o executam é tal que se faz necessário, no transcorrer da música, seja anunciado o nome do intérprete ${ }^{13}$ : Falamansa, Mastruz com Leite, Limão com Mel e outros nomes atrelados a combinações culinárias geralmente sinalizam os protagonistas desse tipo de repertório. Tal versão "movente" (VALENTE, 2003) ${ }^{14}$ do forró atesta como a alteração de poucos elementos da performance implicam em diferentes formas de recepção e fruição ${ }^{15}$.

0 pagode de raiz, na sua origem, deriva-se do samba, na década de 1940. Tem sua continuidade com nomes como Almir Guinéto, Zeca Pagodinho, Fundo de Quintal,
Jovelina Pérola Negra e Nei Lopes. Em 1990, conheceria a versão criada pelas gravadoras, que vendeu milhares de discos ${ }^{16}$. A lista de "pagodeiros" é grande: Da Melhor Qualidade, Dudu Nobre, Exaltassamba, Grupo Molejo, Os Travessos, Só pra Contrariar, Negritude Júnior. Aqui se introduzem os instrumentos eletrônicos não pelos timbres novos, pelos ruídos de linguagem, mas tão simplesmente como versão de baixo orçamento que substitui o naipe de cordas. Desenvolve-se uma sonoridade sem respiração, tônus e articulação precisa dos modos de ataque do instrumentista, que se esvaem nas notas do som infinito do sintetizador- que somente se extingue com a interrupção da energia elétrica...

\section{Uma playlist da virada do segundo milênio}

0 panorama musical dos últimos anos do século $X X$ é amplo e conta com nomes de destaque nos mais diferentes gêneros e formas de expressão, alguns deles de carreira longeva. Encabeçam essa lista inicial os nomes já consagrados na canção brasileira (comumente denominada MPB), oriundos desde a Bossa Nova (tal é o caso do epígono João Gilberto) e aqueles que, ingressados na mídia, quando da participação em festivais de música acabaram acariciados pela intelligentsia. Aqui se encontram Chico Buarque, Edu Lobo, Geraldo Vandré, em grande medida compondo canções críticas (de protesto), os militantes de movimentos culturais (sobretudo a Tropicália): Caetano Veloso, Gilberto Gil, Gal Costa. Mais voltados ao gosto popular, o rock deu audibilidade a artistas que teriam carreira longa e prolífica, como a sempre enfant terrible Rita Lee e ao comedido Roberto Carlos (em sua fase inicial de carreira).

Os sertanejos teriam longos dias de estrada e alto-falantes - sobretudo porque insistentemente rememorados em novela de grande audiência ${ }^{17}$ e representam uma volumosa parcela da população. Não será por acaso que vários dos jingles políticos elegerão as baladas sertanejas para veicular suas mensagens. Chitãozinho e Xororó, Zezé de Camargo e Luciano, Rio Negro e Solimões, Leonardo, Daniel (estes mais voltados a um sertanejo romântico, sobretudo após a morte dos seus pares de dupla Leandro e João Paulo, respectivamente), Roberta Miranda, Sula Miranda são alguns dos nomes que permanecerão, ininterruptamente, durante o período. Outras gerações surgiriam e algumas preexistentes passariam por mudanças contundentes. É o caso dos ex-mirins Sandy e Júnior, que dariam adeus à infância, mudando radicalmente o seu repertório. Sandy se casa e tentará passar a imagem de cantora madura, voltada a um repertório mais refinado e escolarizado ${ }^{18}$.

A despeito de um congestionamento, na paisagem sonora, da entoação "choramingosa", dos monótonos violinos "de plástico", dos apelos pouco sutis à anatomia do corpo humano (particularmente às partes pudendas femininas), os gêneros de origem regional ainda conseguiriam seguir seu caminho. Para além 
dos já consagrados Dominguinhos, Renato Borghetti (Borghettinho) e outros músicos que há décadas se dedicam à preservação e renovação da música regional, outros nomes, tais como o gaúcho Vitor Ramil, Mestre Ambrósio, Cascabulho, Chico Science e Nação Zumbi constam entre os músicos que desenvolvem trabalho a partir de elementos extraídos da cultura popular e do folclore. Antônio Nóbrega vai mais longe: inicialmente, violinista erudito, integrante do movimento Armorial de Ariano Suassuna, parte em busca de sua linguagem própria. Além de criador, desenvolve importante trabalho educativo no Brincante, na capital paulista.

A paisagem sonora do período abrigaria, também 0 universo kitsch e o humor; o escárnio e a paródia. Aqui se reúnem casos particulares, tal como o veterano da Jovem-Guarda Reginaldo Rossi ${ }^{19}$, migrado para o "cafona", faz companhia ao cearense Falcão. Ocorre que Falcão que faz do "brega" sua bandeira estética, pelo viés paródico, com bastante competência: a persona que criou pratica um contraste justapondo palavras de baixo calão, a desafinação proposital a um arranjo instrumental muito bem elaborado, com recursos de estúdio de alto padrão. Tangos e tragédias, do extremo sul do país, já crê na existência de um país fictício, a SbØrnia - com algumas semelhanças "casuais" com o Brasil... Os Kraunus e Pletskaia - na verdade, personagens criados pelos gaúchos Hique Gómez e Nico Nicolaiewsky - se valem de uma atmosfera "kitschtrágica", desenvolvida a partir de repertórios como os de Vicente Celestino, Alvarenga e Ranchinho, passando por Jimmy Hendrix e outros mais.

No campo da música voltada ao experimentalismo, Mauricio Pereira e André Abujamra desenvolvem trabalhos individuais, após a dissolução do grupo Os Mulheres Negras a "menor big band do mundo", no dizer de seus fundadores. Tom Zé, Jorge Mautner estão entre os nomes que vêm contribuindo num campo mais experimental da música. Zeca Baleiro, Chico César, Otto são outros músicos fora do sudeste que têm oferecido um repertório diferenciado, com um grau de originalidade a se considerar. Também cabe ressaltar que, da vertente por onde a linguagem musical busca novas direções, sobressaem nomes como os "cantautores" Zélia Duncan, Adriana Calcanhoto, Leila Pinheiro, Zizi Possi, Vânia Bastos, Na Ozzetti, Luiz Melodia, José Miguel Wisnik, Luiz Tatit.

Igualmente as religiões descobririam que a música tem o poder de angariar fiéis... e mais fundos que os dizimos dos cultos. Muitos sacerdotes e sacerdotisas converteram-se em pop stars, comparáveis aos ídolos de rock, tanto na sua performance, quanto nas suas estratégias de ação. Detentores de concessões de estação de rádio e televisão gravam seus discos, logo transmitidos pelos satélites, retroalimentando, assim, a indústria da fé com fartura de anunciantes e altos índices de audiência. Em termos musicais, contudo, não importam as diferenças de credo; tampouco as formas de persuasão dos fieis: evangélicos, católicos, gospel, na verdade, não se deixam furtar ao inevitável modelo pop convencional, servindo-se de todos os gêneros em voga no momento. Somente o conteúdo das letras se mantém, com menções religiosas, especialmente passagens ou ensinamentos da Bíblia. Padre Marcelo Rossi, da Renovação Carismática (católica) vendeu milhões de discos no final do século XX e serviu de protótipo a outros padres-cantores-dançarinos, ensinando o caminho das pedras para locupletar os cofres da Igreja. Mantém-se como nome importante no casting das gravadoras, não obstante a derrocada da indústria fonográfica ${ }^{20}$.

Por fim, mantêm seus postos os consagrados nichos de consumo: os românticos de há vários anos (Daniel, Leonardo, Roberto Carlos, Fábio Jr.) e décadas (Angela Maria, Cauby Peixoto); os roqueiros: Jota Quest, Skank, Charlie Brown Jr., Ana Carolina, Pitty, além dos veteranos Nando Reis e Rita Lee ${ }^{21}$.E teremos também os rappers DJ Dolores (Hélder Aragão), que já acompanhou os internacionais Bjork, Mobby, Cold Play, Pavilhão 9, Gabriel o Pensador, Marcelo D2, Rappin Hood, Facção Central, DJ Patife. Em número crescente surgirá o funk, em diversas ramificações ("batidão", "proibidão").

\section{Só para contrariar... Deixa a vida me levar...}

Exposto esse sintético panorama de tendências estéticas musicais, passo para uma aproximação entre os governos e governantes. Comecemos pela mais singela e, geralmente, de curta duração: o jingle publicitário. Esta é uma das maneiras segundo as quais se cria e desenvolve a imagem de um político, através da música. Escolhemse canções estróficas, tonais,em gêneros populares, tais como marcha, samba, sem serem desprezados os derivados do pop e do rock. Nas últimas campanhas, especialmente os ritmos nordestinos, como o xote e o forró, além das toadas sertanejas foram os preferidos pelos idealizadores das campanhas. $\mathrm{Na}$ maioria dos casos, os cantores lançam mão de uma impostação vocal tensa, estridente e/ou nasalada - sobretudo quando se opta pelos gêneros de tradição nordestina. A locução, em contrapartida, convida speakers de alta nomeada, como Ferreira Martins (no caso do PSDB) ou Reinaldo Gonzaga (PT) para as narrações em off, adotando o protocolo de projeção vocal, pronúncia e entonação. Ultimamente, entretanto, os marqueteiros vêm se dando conta da importância de incluir vozes de pessoas mais comuns, ou sotaques regionais.

0 jingle da primeira campanha de Fernando Henrique Cardoso, Levanta a Mão, foi composto por Sérgio Mineiro, Sérgio Campanelli, César Brunetti e Maurício Novaes. Baseado no slogan, que anunciava cinco itens como propostas fundamentais do seu governo, conseguiu alta popularidade, sobretudo com a adesão do cantor e acordeonista Dominguinhos, com a peça "Levanta a mão". Posteriormente, o jingle foi reaproveitado em outras campanhas do PSDB nas eleições seguintes (José Serra, 2002 e Geraldo Alckmin, 2006), com algumas variações no arranjo e na letra ${ }^{22}$. 
No caso de Lula, escolheu-se o hit acidental, composto para a eleição de 1989. 0 músico Hilton Acioli relata, em entrevista concedida ao repórter Haroldo Sereza, com imagens e edição de Derek Sismotto como surgiu a peça publicitária; como a sua composição se tornou um grande hit e como foi reapropriada, em 1994 e 2003. Em outra versão, o jingle acabou acoplando trechos do Gilberto Gil, do Chico Buarque e Djavan, com acompanhamento de Wagner Tiso (1989) "Sem medo de ser/ sem medo de ser feliz"; "olê, olê-olê-olá / Lula, Lula"; "Lula lá/ brilha uma estrela". Dentre outras qualidades, destaca a importância do andamento, compatível com a passeata ${ }^{23}$.

Isto posto, insisto que o vínculo entre o candidato e sua imagem criada através da publicidade, não marca definitivamente o mandante, assim como caracterizou o candidato: após as eleições, muitas situações mudam e, não raro, todos os signos engendrados, no sentido de conduzir o candidato ao cargo acabam esquecidos. É bem verdade que a canção composta por Acioli tem características especiais e agrega outros liames simbólicos que lhe garantem uma permanência por longa data, na memória coletiva - sobretudo se tomarmos as lembranças de pessoas que viveram momentos como as "diretas-já" e a primeira candidatura de Lula, para presidente.

Ainda persistindo nesse exercício de risco, ousaria sugerir que, no caso do governo Fernando Henrique Cardoso talvez seja pagode o gênero musical que mais esteja mais afinado com o governo- em que pese o estereótipo criado em torno da figura do presidente, tido como representante da burguesia, de hábitos aristocratas e de gosto refinado. Se observarmos o conjunto da equipe do governo e seus aliados, parece ter havido um desafino conflituoso entre a tentativa de implantar o high tech e as ações efetivamente viabilizadas por uma equipe extremamente conservadora (vide o partido do vice, o presidente da Câmara...): os mesmos violinos "de plástico" (VALENTE, 1999), em alta-fidelidade acústica, parecem apontar para o contraste entre requinte $e$ "jequice" 24 , manifestada pelo alto comando do governo de então. Latifundiários - coronéis - com muitos fundos (financeiros) e pouca profundidade intelectual (escolaridade insuficiente), novos-ricos, "emergentes" na sociedade graças à habilidade com operações bancárias de alta monta acabariam por compor a audiência que lota as salas de espetáculo dos novos ídolos e celebridades midiáticos. Elevados às cumeadas da visibilidade graças a estratégias promocionais das gravadoras, tais intérpretes não demonstrariam ter, contudo, o lastro que assegure sua sobrevida por longo tempo - tal qual a volatilidade do capital que o criou.

De outra parte, existe, igualmente, uma parcela de público cuja formação intelectual é precária e que procura se conferir um status quo de requinte estético, bom gosto e sabedoria. Para tanto, adquire assinaturas de concertos de orquestras sinfônicas de renome, frequentadas pela alta burguesia e noticiadas pelas colunas sociais da mídia impressa e audiovisual.
0 governo capitaneado pelo ex-torneiro mecânico e líder sindical Luís Inácio Lula da Silva foi a grande novidade do fim do segundo milênio, não apenas pela sua origem - um homem do povo-, como também pelas expectativas diversas que suscitou: pela primeira vez, na história recente do país, segmentos marginalizados e minorias acreditavam que poderiam ter voz, e que seus brados seriam imediatamente atendidos. Esta parcela, a princípio, entusiasmada - o mundo acadêmico de corrente filosófica de esquerda, os ambientalistas, a igreja católica progressista, os cidadãos sem-terra (MST), os homossexuais, transexuais e afins (GLBT) - todos aguardavam ansiosamente o momento das grandes mudanças na lei e no status social; na colocação em prática dos seus direitos de cidadania. Enquanto todos esses grupos se manifestavam, parece ter falado mais alto o nicho do capital financeiro internacional, em seu discreto silêncio inquietante...

Qual terá sido a trilha sonora que tenha caracterizado o governo Lula? Ou, melhor dizendo: Houve, de fato, uma trilha sonora dominante do governo Lula? Se os dois mandatos não foram suficientes para iconizar um protótipo, uma coisa parece certa: tomando como referência a representatividade ${ }^{25}$ pelo mundo artístico, 0 "arranjador" deva ter sido o cantautor-ministro Gilberto Gil - não apenas por ter sido membro do primeiro escalão do governo, mas, sobretudo, porque demonstrou ter acolhido todos os naipes possiveis dentro daquilo que se convencionou chamar "música popular brasileira", ou, simplesmente, MPB. Pelo menos no que diz respeito à imagem do país no exterior, algo que parece ter ficado evidente no dia em que se pôs a tocar com Koffi Anan em cerimônia no salão nobre da ONU, quando da homenagem póstuma às vítimas do atentado no Iraque e, em especial, ao embaixador Sérgio Vieira de Melo ${ }^{26}$. Esta seria apenas uma, dentre as várias aparições de Gilberto Gil no cenário internacional, enquanto ministro de estado da cultura.

0 governo Lula foi entremeado de algumas efemérides internacionais que, por razões simbólicas, veio a chamar ao palco muitos músicos: No ano de 2005, comemorouse o Ano do Brasil na França - Brasil, Brasis ${ }^{27}$. Dentre as atrações, a "funkeira" Tati Quebra Barraco, ao lado de veteranos como Caetano Veloso, Gilberto Gil, Daniela Mercury e Carlinhos Brown, Marcelo D2, Dudu Nobre, Maria Rita, trios elétricos da Bahia e de Pernambuco, mangue beat e forró. A festa nacional do dia 14 de julho foi comemorada com shows de músicos brasileiros e acompanhada pelo presidente Lula e o prefeito de Paris, Bertrand Delanöe, na Bastilha ${ }^{28}$, tendo como participantes nomes como Gal Costa, Lenine, Jorge Mautner, Seu Jorge, Dig Bill (Ilê Aiyê). A torre Eiffel vibrou ao som de clássicos como A garota de Ipanema e às luzes verde-amarelas.

0 segundo mandato não apresentou mudanças muito substantivas, incluindo novos protagonistas que tenham se tornado paradigmas na política. Em contrapartida, debates sobre direitos intelectuais, programas de incentivo e promoção de eventos teve grande efervescência. Gilberto Gil alegando ter de retomar a vida artística e 
empresarial cedeu seu posto ao sociólogo Juca Ferreira (João Luiz Silva Ferreira), então secretário executivo da pasta, em 31 de julho de 2008. Ferreira permaneceu no cargo até o final do governo Lula (2011). Exposto isto, talvez seja possivel arriscar dizer, a respeito da trilha sonora do governo Lula, que ela mais se assemelhe a um grande potpourrit musical, composto de vários fragmentos assimétricos e multifacetados, costurados de acordo com as possibilidades, tal como a dessemelhança entre os supostos aliados políticos (que entraram e saíram de circulação) ${ }^{29}$, seus detratores e "companheiros".

Enfim, nesse caldeirão de diversidades, em várias instâncias, as pessoas parecem ter aprendido a dançar todas as modas: acertam o passo e a fórmula de compasso, mudando a coreografia ao sabor das novidades e dos noticiosos (escândalos, trocas de executivos, tragédias naturais, matanças...). Modas entram e saem, retornando, às vezes transfiguradas, mas preservando elementos formais. Ao garantirem sua vaga na paisagem sonora, pelo menos por algum tempo, fixam-se como memória cultural. De certo modo, essa situação se percebe nas matinês dançantes frequentadas pelos idosos, não mais interessados nas mudanças de governo. Tendo vivido "muitos carnavais", querem, antes de tudo, deliciar-se com os hits de todos os tempos e lugares: do samba ao bolero, passando pelas baladas românticas, nacionais e internacionais, os covers do rock, da música latina e quantas mais forem as peças de repertório que venham a animar os salões, criando momentos de descontração em solo firme ou "emoções em alto mar"30. Deixa a vida me levar!

\section{Ai, se eu te pego...}

Muitos são os elementos e funções que estabelecem vínculos entre paisagens sonoras e as trilhas musicais. Tentar tomá-los todos, a uma só vez, é tarefa fadada à frustração. Nesse sentido, o papel das mídias, analisadas em sua especificidade, poderia trazer novos insumos para este estudo empírico como, por exemplo, todas as razões que determinam o longo sucesso da canção "Ai, se eu te pego", do paranaense Michel Teló, em escala planetária.

Dirigindo a atenção para o tempo presente, percebe-se que o atual governo, de Dilma Rousseff, já testemunha algumas mortes tecnológicas e transformações que exacerbam o que já havia sucedido nos mais de 15 anos que antecederam o seu mandato: 0 fim do walkman, em outubro de 2010; a "velhice" precoce do l-Pod, aos dez anos de existência, em 2011, ao mesmo em que o antigo LP volta triunfante (e com custo alto).

Em contrapartida às extinções, o desenvolvimento tecnológico possibilitou a criação das redes sociais, com consequências importantes na formação de novas sensibilidades, hábitos de escuta e fruição dos repertórios musicais: a televisão em live streaming, a música para telefone celular, a "nuvem" para armazenar música e outros arquivos digitais... Sem deixar de mencionar o crescimento do repertório armazenado no sítio Youtube.com, que vem possibilitando ressuscitar do passado maciçamente um vasto arsenal sígnico para 0 momento presente, ao mesmo tempo em que viabiliza o lançamento de novos astros, a partir de uma "fabricação" com equipamentos domésticos, em produções caseiras. São acontecimentos impactantes e de repercussão que, muito possivelmente, farão do universo midiático ainda mais visual do que auditivo... e também mais imiscuido de novas misturas. (Mas isto já é assunto para outro ensaio...)

Tratar de temas no âmbito das linguagens da música é, de fato, tarefa difícil, dada a sua natureza autorreferente. Mas ao mesmo tempo, o obstáculo se converte em tarefa altamente convidativa, pois não será a ambiguidade, a multiplicidade semântica uma das riquezas maiores da comunicação, pelas linguagens da música? Pretendi, ao longo destas páginas, apresentar algumas preocupações que percutem e repercutem a minha área de atuação acadêmica: a música e sua interface com as mídias. Se algumas afirmações possam carecer de uma abordagem científica tradicional, não será por isso que terei falhado na sustentação das afirmativas: houve rigor na obtenção de fontes. Longe de haver concluido esta quase-viagem a um universo edificado por paisagens sonoras, espero haver instigado o leitor a colocar em prática a sua "audição clara" e exercitar, por sua própria conta e risco, novas formulações teóricas. Se a pesquisa mostrou-se insuficiente e superficial, ao menos foi possivel evidenciar que, por intermédio desses estudos, é possivel obter informações valiosas, que poderão contribuir para um conhecimento mais aprofundado a respeito do Brasil. "Um país de todos", que também necessita se conhecer pelos ouvidos... 


\section{Referências bibliográficas}

ALBIM, Ricardo Cravo. Dicionário MPB. Disponível em http://www.dicionariompb.com.br. Consultado em junho de 2012.

AMARAL, Euclides (2005). O movimento hip hop. Disponivel em: http://www.baixadafacil.com.br/euclidesamaral/hiphop. htm. Consultado em 26 de abril de 2005.

GONZÁLEZ, Juan Pablo. Musicología popular en América Latina: síntesis de sus logros, problemas y desafíos. Revista musical chilena. [online], vol. 55, n. 195, 2001. Disponivel em: http://www.scielo.cl. Consultado em 16 de maio de 2005

MARCADET, Christian. Fontes e recursos para a análise da canção e princípios metodológicos para a constituição de uma fonoteca de pesquisa. In: VALENTE, Heloísa de A. D.(org.): Música e mídia: novas abordagens sobre a canção. São Paulo: Via Lettera; FAPESP, p. 114-145, 2007.

NEDER, Álvaro: 0 estudo cultural da música popular brasileira: dois problemas e uma contribuição. In: Per Musi. Belo Horizonte, $n^{\circ} 22,2010$, p. 181-195.

SANTAELLA, Lúcia A cultura das mídias. São Paulo: Experimento, 1996.

SCHAFER, R. Murray. A afinação do mundo. São Paulo: Edunesp, 2001.

VALENTE, Heloísa de A. D., NUNES, M. R. F. Padre Marcelo \& Amigos: uma questão bizantina? In: Atas do XX Congresso Brasileiro de Ciências da Comunicação - Intercom (CDROM). Rio de Janeiro, 1999. Não paginado.

VALENTE, Heloísa de A. D. Opala preto e outras pérolas: performance de um veículo numa paisagem sonora globalizada. Cadernos da Pós-Graduação, ano 3, vol. 3, n¹. Programa de Pós-Graduação Mestrado em Artes/ Mestrado e Doutorado em Multimeios. Campinas: Instituto de Artes/ Unicamp, 1999.

0 espírito do tempo, os tempos do espírito: nos (com)passos dos beats dos hits In: Revista Ghrebh_, no 1, outubro 2002. Disponivel em: http://revista.cisc.org.br/ghrebh1/artigos/01heloisa28092002.html. Acesso em 25 jan.2011. Não paginado.

As vozes da canção na mídia São Paulo: Via Lettera; FAPESP, 2003.

A canção das mídias: objeto de escuta; objeto de estudo. In: VI Fórum do Centro de Linguagem Musical. Anais. São Paulo: Departamento de Música da ECA-USP, 2004.

(org.) Música e cultura das mídias: apontamentos e exercícios de clariaudiência. Osasco: Da Vinci Editora, 2010.

(org.) Música e cultura das mídias: apontamentos e exercícios de clariaudiência. Osasco: Da Vinci Editora, 2011.

YÚDICE, George. A funkização do Rio. HERSCHMANN, Michael (Org.). Abalando os anos 90: punk e hip-hop. Globalizção, violência e estilo cultural. Rio de Janeiro: Rocco, 1997.

ZUMTHOR, Paul. Introdução à poesia oral. São Paulo: Hucitec; Educ, 1997.

\section{Fontes na internet}

MICHAEL, Andréa. Euforia alagoana: 0 ex-presidente Fernando Collor fez de seu $50^{\circ}$ aniversário o ensaio geral para o regresso à política a partir do ano 2000.In:Época (on-line). epoca.globo.com/edic/19990816/brasil2.htm. Acesso: 30.jun.2012.

Autor do Lula- lá fala sobre o "jingle". Entrevista de Hilton Acioli a Haroldo Sereza .Especial UOL Eleições 1989 (notícias. uol.com.br/1989). Disponivel em: http://www.youtube.com/watch?v=rqRRLod-s3l. Acesso: 30 jun. 2012.

Peças raras (blog)http://pecasraras.blogspot.com.br/2010/10/musica-para-eleger-fhc-x-lula-em-1994.html. Acesso em 30 jun. 2012.

MENDES, Gilberto: 0 papel das mídias e produtos tecnológicos na composição musical palestra proferida para o Centro de Estudos em Música e Mídia -MusiMid, em 24 jun. 2005. http://www.musimid.mus.br/videos.htm. Acesso em 30 jun. 2012.

Folha de S. Paulo, em $1^{\circ}$ de janeiro de 1999, p.1, caderno 4.

Ministério da Cultura: http://www.cultura.gov.br/site/2005/03/17/brasil-na-franca-2/. 


\section{Notas:}

10 conceito, criado por Murray SCHAFER (2001) traça um paralelo à experiência da clarividência e aponta para a necessidade de dirigir a atenção para os fenômenos sonoros que, por certo, podem ser portadores de informações relevantes.

2 Entenda-se o conceito de paisagem sonora (adaptação do neologismo soundscape), como o meio ambiente acústico, de qualquer natureza, assimilado no eixo espaço-tempo. SCHAFER adverte que a paisagem sonora tende a ser progressivamente mais barulhenta, com o passar do tempo (SCHAFER, 2001).

3 Não podendo me alongar em considerações a respeito, remeto o leitor à leitura do texto de Álvaro Neder: 0 estudo cultural da música popular brasileira: dois problemas e uma contribuição (NEDER, 2010).

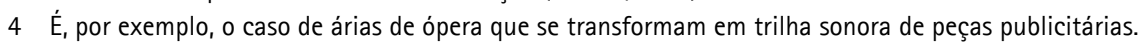

5 Uma análise detalhada, acerca das implicações tocantes à canção, pode ser consultada em VALENTE (2003).

6 Some-se que além do número reduzido, uma grande massa dos escritos é fruto da lavra de autores não isentos - os fãs - ou visando a outros interesses e preocupações longe do campo artístico. Parte expressiva dos trabalhos universitários é de cunho histórico, antropológico e linguístico-literário, sociológico. Nestes casos, a preocupação com a qualidade artística da obra musical não é a prioridade. Desse modo, gêneros como o funk, hip hop e outros, normalmente relacionados prioritariamente como a música das camadas desfavorecidas economicamente são recebidos com entusiasmo, pelos autores, à medida que garantem a "sociabilidade" grupal, promovendo "consciência identitária", ou a redução da violência na comunidade; no caso da relação letra e música, valoriza-se a "eficácia" comunicativa entre ambas. Mais recentemente, os programas de pós-graduação vêm manifestando interesse nos estudos dirigidos à canção, sobretudo àquela denominada "canção popular urbana", com resultados interessantes. Na maioria dos casos, trata-se de análises de composicionais, relacionando a evolução da linguagem de compositores através de suas obras.

7 Um exemplo típico é o funk: acolhido, por uma comunidade de pesquisadores de prestígio como de extrema relevância, a mesma manifestação musical é, para outros estudiosos, com o mesmo prestígio intelectual, algo sem maior interesse - quando não desprezível...

8 Não se trata, absolutamente, de minimizar instâncias como o poder de persuasão da mídia sobre a opinião pública, mas de considerar que, especialmente a liberdade de expressão permite avaliar as manifestações populares como sinceras.

9 Dentre eles, destaco o texto Opala preto e outras pérolas performance de um veículo numa paisagem sonora globalizada, originado de um debate de uma lista de discussão e apresentado no XI Encontro Nacional da ANPPOM (Associação Nacional de Pesquisa e Pós-Graduação em Música), realizado no Instituto de Artes da Unicamp (24 a 28 de agosto de 1998). 0 texto encontra-se publicado na integra em um periódico (VALENTE, 1999).

10 Em 2006, no Programa de Pós-Graduação em Música do Instituto de Artes da UNESP e, desde 2008, no Programa de Pós-Graduação em Música do Instituto de Artes da ECA-USP. Parte dos trabalhos desenvolvidos pelos alunos foi publicado em hipertexto (VALENTE (org).(2010; 2011)

11 Um exemplo interessante se encontra na canção Menina veneno. 0 hit do então desconhecido Ritchie tomou conta de todas as estações de rádio em período integral, no ano de 1983. Tendo-se em conta que a época não comportava a reprodução digital em série, bem como outras mídias (Youtube, redes sociais) a força da canção (e do jabá) tiveram peso significativo na caracterização da paisagem sonora daquele ano.

12 No caso da música verificar-se-á, mais tarde, essa mesma possibilidade de escolha. Aliada à possibilidade de efetuar cópias a baixo custo financeiro, gratuitas ou pirateadas - propiciaria a escuta, e reprodução em série de músicas, sob a forma de arquivos sonoros.

13 Em certa medida, corresponde a uma recuperação do procedimento das primeiras gravações, quando os dados da gravação eram anunciados, antes do início da faixa gravada.

14 Desenvolvi várias reflexões sobre o conceito de "movência", cunhado por Paul Zumthor (1997). A movência é um processo tradutório do próprio signo (no caso, musical), que faz com que a obra se reconfigure. Não se limita a mudanças de letra ou arranjo instrumental, mas também a aspectos mais sutis, como andamento, enunciação vocal, projeção da voz, espacialização do som etc..

15 Existe, ainda, um dado importante que é a temática expressa nas letras das canções e sua função junto aos receptores. Não sendo interesse deste texto estabelecer juízos de valor ou mesmo analisar em detalhes as transformações sofridas por este gênero, bem como os outros que comentarei, a seguir, permito-me encerrar as descrições aqui, já quem sobre o forró, existem trabalhos consistentes desenvolvidos. 0 diferencial inegável entre a versão tradicional é o forró universitário é que este último não existe sem a alimentação elétrica.

16 No verbete pagode, do Dicionário da MPB Cravo Albim, encontra-se a curiosa observação: "Sua repercussão chegou até a Copa Mundial de 2002, no eixo Japão-Coreia, quando muitos dos jogadores que arrebataram o pentacampeonato para o Brasil, foram filmados e fotografados cantando esse tipo de música." (ALBIM 2005).

17 Cite-se, por exemplo, a telenovela América (Rede Globo, 2005), cujo argumento centra-se na vida dos peões de boiadeiro e seu entorno.

18 A imagem cult se ratifica, a ponto de convidar para acompanhá-la o pianista Marcelo Bratke, em 2011.

19 Após sucesso na Jovem Guarda, sua carreira arrefeceu-se, até se tornar epígono daquilo que se convencionou designar como "cafona". Ao que parece, a "conversão" se deu após ter sido convidado para animar o aniversário de 50 anos de Fernando Collor. 0 vasto repertório de canções bregas parece ter realimentado a sua carreira. Consulte-se: Euforia alagoana: 0 ex-presidente Fernando Collor fez de seu $50^{\circ}$ aniversário o ensaio geral para o regresso à política a partir do ano 2000. In: Época (on-line). epoca.globo.com/edic/19990816/brasil2.htm. Acesso: 30/jun.2012.

20 Conforme estatística divulgada no jornal Folha de São Paulo foi o disco Canções para louvar ao Senhor foi o campeão de vendas pela Polygram em 1998 e o segundo mais vendido em todo o Brasil, sendo superado apenas por Leandro e Leonardo (BMG, 3 000 000). Em 2011, o Ágape Musical, produto conjuminado ao livro Ágape (igualmente best seller, com mais de cinco milhões de exemplares vendidos) (10 de janeiro de 1999, caderno 4, p.1)

21 Na época, anunciou a saída dos palcos em 2012, o que parece verificar-se, atualmente.

22 Para se criar uma imagem "nordestinizada" do candidato, os "marqueteiros" apelaram para o produto nacional e popular, fazendo-o substituir jantares em restaurantes finos, por buchada de bode, em feira popular, montar em jegue etc. Informações colhidas em: http://pecasraras. blogspot.com.br/2010/10/musica-para-eleger-fhc-x-lula-em-1994.html. Acesso: 30. Jun. 2012

230 depoimento pode ser visto no endereço: http://www.youtube.com/watch?v=rqRRLod-s3l. Acesso: 30. Jun.2012.

24 Aqui reproduzo o termo utilizado por Nelson Motta na entrevista. Referia-se, mais especificamente, ao então presidente José Sarney e a sua relação com a lambada.

25 Aqui cito o compositor Gilberto Mendes, para quem o lema um país de todos não se estende à música de concerto... (cf. palestra proferida para o Centro de Estudos em Música e Mídia -MusiMid, em 24 jun. 2005). http://www.musimid.mus.br/videos.htm. Acesso: 30 jun. 2012.

26 Reproduzo a notícia, conforme assinalado no Terra Notícias, em 19/09/2003:"0 músico e ministro de Cultura do Brasil, Gilberto Gil, fez hoje um show no Hall da Assembleia Geral da ONU em memória das 22 pessoas que morreram no atentado à sede dessa organização em Bagdá. 0 concerto também foi realizado pela celebração do Dia da Paz Internacional e foi apresentado pelo próprio secretário-geral da ONU, Kofi Annan, que lembrou o compromisso dessa organização com "a paz e a dignidade humana". No final do show, Gil levou Annan para cima do palco, onde o secretáriogeral tocou atabaque.Gil e Kofi Annan tocam juntos na ONU pela paz". In: Terra notícias: http://noticias.terra.com.br/mundo/noticias/0,0I146449El865,00-Gil+e+Kofi+Annan+tocam+juntos+na+ONU+pela+paz.html. Acesso: 30 jun. 2012.

27 Sobre o evento, consulte-se a descrição do projeto na página do Ministério da Cultura (Minc) em: http://www.cultura.gov.br/site/2005/03/17/ brasil-na-franca-2/. 
28 Lula aclamado em show de música brasileira na Bastilha. In Uol: Últimas Notícias. Disponivel em : http://noticias.uol.com.br/ultnot/afp/2005/07/13/ ult34u130304.jhtm (13/07/2005). Acesso: 30 jun 2012.

29 Aliás, esta ideia aparece no próprio logotipo do governo, onde a palavra Brasil aparece em letras de cores e estampas diferentes, tal como um bordado feito de retalhos. Como aposto, segue a frase "um pais de todos".

30 Referência aos cruzeiros temáticos, no qual Roberto Carlos é o convidado de honra. Devido ao sucesso, o evento vem se repetindo anualmente, no verão, com saída do porto de Santos, com duração de três dias.

Heloísa de A. Duarte Valente é Pesquisadora do CNPq, Doutora em Comunicação e Semiótica (PUC-SP), com estágio junto à Escola de Altos Estudos em Ciências Sociais (EHESS, Paris), e pós-doutoramento junto ao Dept. de Cinema, Rádio e Televisão da Escola de Comunicações e Artes da Universidade de São Paulo (CTR- ECA-USP). É autora de Os cantos da voz: entre o ruído e o silêncio (São Paulo: Annablume, 1999) e As vozes da canção na mídia (Via Lettera/FAPESP, 2003); e organizadora de diversas obras na área interdisciplinar de música e comunicação. É fundadora Centro de Estudos em Música e Mídia - MusiMid e idealizadora e responsável pelos Encontros de Música e Mídia (desde 2005). Atua como pesquisadora e docente junto ao Programa de Pós-Graduação em Música ECA-USP e no Mestrado em Políticas Públicas da Universidade de Mogi das Cruzes. 